\title{
Classifying Aging As a Disease: The Role of Microbes
}

\author{
Michael S. Lustgarten * \\ Jean Mayer USDA Human Nutrition Research Center on Aging, Tufts University, Boston, MA, USA
}

Keywords: aging, inflammation, oxidative stress, insulin resistance, telomere shortening, Alzheimer's disease, cardiovascular disease (CVD), cancer

Recent publications have proposed that aging should be classified as a disease (Bulterijs et al., 2015; Zhavoronkov and Bhullar, 2015; Zhavoronkov and Moskalev, 2016). The goal of this manuscript is not to dispute these claims, but rather to suggest that when classifying aging as a disease, it is important to include the contribution of microbes.

As recently as $\sim 115$ years ago, more than half of all deaths were caused by infectious diseases, including pneumonia, influenza, tuberculosis, gastrointestinal infections, and diphtheria (Jones et al., 2012). Since then, the establishment of public health departments that focused on improved sanitation and hygiene, and the introduction of antibiotics and vaccines allowed for a dramatic decrease in infectious disease-related mortality (Report, 1999). In 2010, the death rate for infectious diseases was reduced to $3 \%$ (Jones et al., 2012). Simultaneously, as infectious disease-related mortality rates have decreased, global lifespan has increased from $\sim 30$ to $\sim 70$ years (Riley, 2005).

Because death rates due to infectious diseases have been reduced to very low levels, we've forgotten about the adverse effects of microbes on our existence. The fact is, we live in a microbial

\section{OPEN ACCESS}

Edited by:

Alex Zhavoronkov,

The Biogerontology Research

Foundation, UK

Reviewed by:

Ancha Baranova,

George Mason University, USA

Michael Petrascheck,

Scripps Research Institute, USA

*Correspondence:

Michael S. Lustgarten

Michael.Lustgarten@Tufts.edu

Specialty section:

This article was submitted to

Genetics of Aging,

a section of the journal

Frontiers in Genetics

Received: 14 October 2016 Accepted: 21 November 2016 Published: 01 December 2016

Citation:

Lustgarten MS (2016) Classifying Aging As a Disease: The Role of Microbes. Front. Genet. 7:212. doi: 10.3389/fgene.2016.00212 world. Although there are currently $\sim 7$ billion people, in contrast, the total number of prokaryotes and viruses have been estimated at $10^{30}$ and $10^{31}$, respectively (Whitman et al., 1998; Duerkop et al., 2014). Even without including other microbes (e.g., fungi, protozoa), humans are outnumbered by more than $10^{21}$ to 1 ! All of these microorganisms aren't detrimental to human health, but more than 1400 microbial species have been shown to be pathogenic (Taylor et al., 2001).

Even at a young chronological age, microbes find their way into the blood and tissues. Circulating microbial DNA is found in young, healthy adults (average age, BMI: 21 years $<25 \mathrm{~kg} / \mathrm{m}^{2}$ ) (Païsse et al., 2016). Interestingly, levels of circulating bacterial DNA were not homogeneous: some subjects had 3-fold or more circulating bacterial DNA when compared with others. Moreover, various bacterial species are found in skeletal muscle, heart, liver, adipose tissue, and in the brains of young mice (Lluch et al., 2015).

With the passage of time, the barriers responsible for keeping microbes out of us weaken. For example, tight junctions (TJs) connect epithelial cells, thereby minimizing the space in between the cells, and minimizing the ability of microbes to translocate into the blood. TJs are comprised of proteins such as junctional adhesion molecule (JAM), zonulin (e.g., ZO-1), occludins, and claudin. Bacteria and viruses, including Vibrio cholera, Shigella, and rotavirus have evolved mechanisms to impair TJ assembly: $V$. cholera uses a cleavage product from the ZOT protein to dissociate ZO-1 from the cell periphery, ZO-1 binds to the actin-containing tail of Shigella, thereby disrupting the TJ, and rotavirus uses the VP8 fragment of VP4 to dissociate claudin, occludin, and ZO-1 (Guttman and Finlay, 2009). Whether caused by pathogenic microbes or because of defects in host gene expression, levels of many of these tight junction proteins, including JAM-A, ZO-1, and occludin are decreased in old, when compared with young (Tran and Greenwood-Van Meerveld, 2013). Furthermore, although the immune system should protect us against an increase in microbial burden, however, many aspects of the immune response are decreased, whereas others are increased, thereby resulting in dysregulation. This phenotype is known as immunosenescence (Pera et al., 2015). Interestingly, a causative role for microbes on reducing immune function is 
suggested by the finding that young adults infected with cytomegalovirus (CMV) exhibit signs of immunosenescence (Turner et al., 2014).

The impact of decreased barrier function and immunosenescence would be expected to lead to an increase in circulating microbes in old, when compared with young. Although circulating levels of bacterial DNA have yet to be reported in older adults, plasma levels of lipopolysaccharide (LPS), which is found in the outer membrane of gram-negative bacteria, and levels of the receptors that bind to LPS (TLR4) and to bacterial flagellin (TLR5), are elevated in older adults, when compared with young (Qian et al., 2012; Ghosh et al., 2015). In line with this, the incidence of bloodstream infections with LPS-containing Escherichia coli is increased by more than 10 -fold in adults older than 74, when compared with subjects younger than 50 years (Williamson et al., 2013). Similarly, the incidence of bloodstream infections with gram-positive bacteria (Staphylococcus aureus) is elevated by more than 8-17 fold in older adults (Klevens et al., 2007).

What are the consequences of an age-related increase in microbial burden? Microbes and/or microbial products are causatively involved in multiple theories of aging, including insulin resistance, oxidative stress, inflammation, and telomere shortening. In support of this, LPS injection into young, healthy subjects (average age, BMI: 26 years, $<25 \mathrm{~kg} / \mathrm{m}^{2}$ ) causes insulin resistance, as determined by elevated HOMA-IR values (Mehta et al., 2010). Oxidative stress is increased in response to the binding of LPS and bacterial flagellin to their respective receptors (Yuan et al., 2013; Kim et al., 2016). Levels of the pro-inflammatory cytokines IL- 6 and TNF- $\alpha$ are increased when LPS binds to TLR4 (Greenhill et al., 2011). Telomere shortening occurs at a faster rate in the presence of CMV infection (Parry et al., 2016). Interestingly, the prevalence of CMV infection increases from $\sim 20 \%$ in adults younger than 50 years, to $\sim 40 \%$ in $50-70$ year olds, to $100 \%$ in adults older than 70 (Parry et al., 2016). Collectively, these data support a causative role for microbial burden on mechanisms that have been commonly hypothesized to drive the aging process.

Microbial burden is also involved in mechanisms related to age-related disease, including cardiovascular disease (CVD), Alzheimer's disease, cancer, stroke, and diabetes. In support of this, approximately 10 -fold more circulating bacterial DNA is found in CVD patients, when compared with healthy controls (Dinakaran et al., 2014). Oral and gut microbes are found within atherosclerotic plaque (Koren et al., 2011). A causative role for bacteria on cardiovascular disease is supported by the finding that the oral microbe, Porphyromonas gingivalis, causes atherosclerotic plaque formation (Velsko et al., 2014).

Moreover, many of the molecular players related to atherosclerotic plaque formation, including C-reactive protein (CRP), LDL cholesterol, and fibrinogen (Spronk et al., 2004), are protective against infection-related mortality. For example, although injection of Streptococcus pneumonae kills $80 \%$ of wild type mice within 2 days, survival is improved by more than 4-fold in the presence of CRP (Mold et al., 2002). Similarly, although infection with Klebsiella pneumoniae kills all wild type mice within 2 days, survival is significantly improved in mice that are genetically engineered to have elevated circulating levels of LDL cholesterol (Netea et al., 1996). Interestingly, LDL acts as a carrier for LPS (Levels et al., 2005), and is involved in mechanisms that inactivate LPS (Weinstock et al., 1992). Approximately half of all fibrinogen-deficient mice that are injected with $S$. aureus die within 12 days, whereas mice that have wild type levels of fibrinogen are protected (Prasad et al., 2015). In addition, fibrinogen levels are significantly correlated with the amount of bacteria found in blood (Amar et al., 2011). CRP, LDL, and fibrinogen increase during aging (Abbott et al., 1983; Kannel et al., 1987; Herman et al., 2009), findings that support a link between microbial burden with the progression of CVD.

Patients with Alzheimer's disease (AD) have an increased amount of circulating bacteria (spirochaetes) when compared with age-matched, AD-free controls (Miklossy, 1993). Four-fold more Treponema bacteria, 3-fold more herpes simplex virus type I DNA, and fungi, including Candida albicans and Sacharomyces cerevisiae have been found in the brains of $\mathrm{AD}$ patients, when compared with age-matched controls (Riviere et al., 2002; Wozniak et al., 2009; Pisa et al., 2015). Further support for the hypothesis that Alzheimer's disease has a microbial component comes from the finding that $\beta$-amyloid protein $(A \beta)$, which is a key mediator of $\mathrm{AD}$ pathology, is an antimicrobial peptide. $\mathrm{A} \beta$ inhibits the growth of various fungi and bacteria, when compared against the well-known anti-microbial peptide, LL-37 (Soscia et al., 2010). In addition, levels of another antimicrobial peptide, $\beta$-defensin-1, are elevated in $\mathrm{AD}$ brains, when compared with age-matched controls (Williams et al., 2013). These data suggest that the increased prevalence of $\mathrm{A} \beta$ and $\beta$-defensin- 1 that are found in the brains of $\mathrm{AD}$ patients may be a compensatory mechanism to protect the brain against microbial infection.

A role for microbial burden on cancer incidence is supported by the findings that liver tumor amounts and tumor size are significantly increased in the presence of LPS (Dapito et al., 2012), and that exposure to LPS causes pancreatic cancer. Mice treated with LPS develop significantly more advanced pancreatic intraepithelial neoplasias, when compared with untreated controls (Ochi et al., 2012). Beyond LPS, bacteria, viruses, and parasites are associated with or are causatively involved with the progression of various cancers, including $H$. pylori with stomach cancer, the hepatitis $\mathrm{B}$ and $\mathrm{C}$ viruses with liver cancer, the human papillomavirus virus (HPV) with cervical cancer, and the parasite Schistosoma haematobium with bladder cancer (de Martel et al., 2012).

In terms of cerebrovascular disease (stroke), a circulating microbial index comprised of 2 bacterial (Chlamydophila pneumoniae, $H$. pylori) and 3 viral (CMV, herpes simplex virus 1 and 2) species was associated with a $40 \%$ increased risk of stroke (Elkind et al., 2010). Furthermore, various bacteria, parasites, fungi, and viruses, including $H$. pylori, Trypanosoma cruzi, Asperigillus, CMV, and others have been implicated in stroke pathogenesis (Miller and Elkind, 2016). One way that microbial burden may contribute to stroke risk is by the binding of LPS to fibrinogen. Within $10 \mathrm{~min}$ of exposure of fibrinogen to LPS, fibrils and dense, matted deposits are formed (Pretorius et al., 2016). Similarly, the addition of LPS to whole blood results 
in amyloid-like matted deposits and a hypercoagulated state (i.e., blood clots), evidence that provides a link between circulating microbial burden with stroke.

In addition to LPS's causative role on insulin resistance, elevated circulating LPS is associated with a significantly higher risk for the development of type 2 diabetes in middle-aged adults (Pussinen et al., 2011). LPS may not be the only bacterial trigger for inducing insulin resistance. In support of this, blood levels of bacterial DNA are elevated in middle-aged, and in older adults with type II diabetes, when compared with healthy controls (Amar et al., 2011; Sato et al., 2014).

If we are fortunate to avoid these diseases and live to achieve centenarian status, infectious disease as a major cause of death arises again. In Japan, more than $40 \%$ of all centenarian deaths are due infectious diseases, including pneumonia (Tauchi et al., 1999). Similarly, in a larger study of $\sim 36,000$ centenarians from the UK, other than "old age," the leading cause of death was

\section{REFERENCES}

Abbott, R. D., Garrison, R. J., Wilson, P. W., Epstein, F. H., Castelli, W. P., Feinleib, M., et al. (1983). Joint distribution of lipoprotein cholesterol classes. The Framingham study. Arteriosclerosis 3, 260-272.

Amar, J., Serino, M., Lange, C., Chabo, C., Iacovoni, J., Mondot, S., et al. (2011). Involvement of tissue bacteria in the onset of diabetes in humans: evidence for a concept. Diabetologia 54, 3055-3061. doi: 10.1007/s00125-011-2329-8

Bulterijs, S., Hull, R. S., Bjork, V. C., and Roy, A. G. (2015). It is time to classify biological aging as a disease. Front. Genet. 6:205. doi: 10.3389/fgene.2015.00205

Dapito, D. H., Mencin, A., Gwak, G. Y., Pradere, J. P., Jang, M. K., Mederacke, I., et al. (2012). Promotion of hepatocellular carcinoma by the intestinal microbiota and TLR4. Cancer Cell 21, 504-516. doi: 10.1016/j.ccr.2012.02.007

de Martel, C., Ferlay, J., Franceschi, S., Vignat, J., Bray, F., Forman, D., et al. (2012). Global burden of cancers attributable to infections in 2008: a review and synthetic analysis. Lancet Oncol. 13, 607-615. doi: 10.1016/S1470-2045(12)70137-7

Dinakaran, V., Rathinavel, A., Pushpanathan, M., Sivakumar, R., Gunasekaran, P., and Rajendhran, J. (2014). Elevated levels of circulating DNA in cardiovascular disease patients: metagenomic profiling of microbiome in the circulation. PLoS ONE 9:e105221. doi: 10.1371/journal.pone.0105221

Duerkop, B. A., Palmer, K. L., and Horsburgh, M. J. (2014). "Enterococcal bacteriophages and genome defense," in Enterococci: From Commensals to Leading Causes of Drug Resistant Infection, eds M. S. Gilmore, D. B. Clewell, Y. Ike, and N. Shankar (Boston, MA: Massachusetts Eye and Ear Infirmary), 421.

Elkind, M. S., Ramakrishnan, P., Moon, Y. P., Boden-Albala, B., Liu, K. M., Spitalnik, S. L., et al. (2010). Infectious burden and risk of stroke: the northern Manhattan study. Arch. Neurol. 67, 33-38. doi: 10.1001/archneurol.20 09.271

Evans, C. J., Ho, Y., Daveson, B. A., Hall, S., Higginson, I. J., Gao, W., et al. (2014). Place and cause of death in centenarians: a population-based observational study in England, 2001 to 2010. PLoS Med. 11:e1001653. doi: 10.1371/journal.pmed.1001653

Ghosh, S., Lertwattanarak, R., Garduno Jde, J., Galeana, J. J., Li, J., Zamarripa, F., et al. (2015). Elevated muscle TLR4 expression and metabolic endotoxemia in human aging. J. Gerontol. A Biol. Sci. Med. Sci. 70, 232-246. doi: 10.1093/gerona/glu067

Gordon, H. A., Bruckner-Kardoss, E., and Wostmann, B. S. (1966). Aging in germfree mice: life tables and lesions observed at natural death. J. Gerontol. 21, 380-387.

Greenhill, C. J., Rose-John, S., Lissilaa, R., Ferlin, W., Ernst, M., Hertzog, P. J., et al. (2011). IL-6 trans-signaling modulates TLR4-dependent inflammatory responses via STAT3. J. Immunol. 186, 1199-1208. doi: 10.4049/jimmunol.1002971 pneumonia (Evans et al., 2014). In short, over the past 115+ years, we haven't eliminated the adverse effects of microbes on our health, we've merely delayed them!

As an argument against the role of microbes on causing many aspects of aging and age-related disease, it is important to note that host aging does indeed occur in their absence. Although lifespan in microbe-free mice is increased by $20-50 \%$ (Gordon et al., 1966; Tazume et al., 1991), these animals are not immortal. Nonetheless, as presented here, microbes are involved in mechanisms related to aging and age-related disease, and accordingly, I posit that any classification of aging as a disease should include the contribution of microbes.

\section{AUTHOR CONTRIBUTION}

The author confirms being the sole contributor of this work and approved it for publication.

Guttman, J. A., and Finlay, B. B. (2009). Tight junctions as targets of infectious agents. Biochim. Biophys. Acta 1788, 832-841. doi: 10.1016/j.bbamem.2008.10.028

Herman, W. A., Senko, A., Korczowska, I., and Lacka, K. (2009). Assessment of selected serum inflammatory markers of acute phase response and their correlations with adrenal androgens and metabolic syndrome in a population of men over the age of 40. Pol. Arch. Med. Wewn. 119, 704-711.

Jones, D. S., Podolsky, S. H., and Greene, J. A. (2012). The burden of disease and the changing task of medicine. N.Engl. J. Med. 366, 2333-2338. doi: 10.1056/NEJMp1113569

Kannel, W. B., Wolf, P. A., Castelli, W. P., and D’Agostino, R. B. (1987). Fibrinogen and risk of cardiovascular disease. The Framingham Study. JAMA 258, 1183-1186.

Kim, J., Seo, M., Kim, S. K., and Bae, Y. S. (2016). Flagellin-induced NADPH oxidase 4 activation is involved in atherosclerosis. Sci. Rep. 6:25437. doi: $10.1038 /$ srep25437

Klevens, R. M., Morrison, M. A., Nadle, J., Petit, S., Gershman, K., Ray, S., et al. (2007). Invasive methicillin-resistant Staphylococcus aureus infections in the United States. JAMA 298, 1763-1771. doi: 10.1001/jama.298.15.1763

Koren, O., Spor, A., Felin, J., Fåk, F., Stombaugh, J., Tremaroli, V., et al. (2011). Human oral, gut, and plaque microbiota in patients with atherosclerosis. Proc. Natl. Acad. Sci. U.S.A. 108(Suppl. 1), 4592-4598. doi: 10.1073/pnas.10113 83107

Levels, J. H., Marquart, J. A., Abraham, P. R., van den Ende, A. E., Molhuizen, H. O., van Deventer, S. J., et al. (2005). Lipopolysaccharide is transferred from high-density to low-density lipoproteins by lipopolysaccharide-binding protein and phospholipid transfer protein. Infect. Immun. 73, 2321-2326. doi: 10.1128/IAI.73.4.2321-2326.2005

Lluch, J., Servant, F., Paisse, S., Valle, C., Valiere, S., Kuchly, C., et al. (2015). The characterization of novel tissue microbiota using an optimized 16S metagenomic sequencing pipeline. PLOS ONE 10:e0142334. doi: 10.1371/journal.pone.0142334

Mehta, N. N., McGillicuddy, F. C., Anderson, P. D., Hinkle, C. C., Shah, R., Pruscino, L., et al. (2010). Experimental endotoxemia induces adipose inflammation and insulin resistance in humans. Diabetes 59, 172-181. doi: $10.2337 / \mathrm{db} 09-0367$

Miklossy, J. (1993). Alzheimer's disease-a spirochetosis? Neuroreport 4, 841-848. Miller, E. C., and Elkind, M. S. (2016). Infection and stroke: an update on recent Progress. Curr. Neurol. Neurosci. Rep. 16, 2. doi: 10.1007/s11910-015-0602-9

Mold, C., Rodic-Polic, B., and Du Clos, T. W. (2002). Protection from Streptococcus pneumoniae infection by $\mathrm{C}$-reactive protein and natural antibody requires complement but not Fc gamma receptors. J. Immunol. 168, 6375-6381. doi: 10.4049/jimmunol.168.12.6375

Netea, M. G., Demacker, P. N., Kullberg, B. J., Boerman, O. C., Verschueren, I., Stalenhoef, A. F., et al. (1996). Low-density lipoprotein receptor-deficient mice 
are protected against lethal endotoxemia and severe gram-negative infections. J. Clin. Invest. 97, 1366-1372. doi: 10.1172/JCI118556

Ochi, A., Nguyen, A. H., Bedrosian, A. S., Mushlin, H. M., Zarbakhsh, S., Barilla, R., et al. (2012). MyD88 inhibition amplifies dendritic cell capacity to promote pancreatic carcinogenesis via Th2 cells. J. Exp. Med. 209, 1671-1687. doi: $10.1084 /$ jem. 20111706

Païsse, S., Valle, C., Servant, F., Courtney, M., Burcelin, R., Amar, J., et al. (2016). Comprehensive description of blood microbiome from healthy donors assessed by $16 \mathrm{~S}$ targeted metagenomic sequencing. Transfusion 56, 1138-1147. doi: $10.1111 /$ trf.13477

Parry, H. M., Zuo, J., Frumento, G., Mirajkar, N., Inman, C., Edwards, E., et al. (2016). Cytomegalovirus viral load within blood increases markedly in healthy people over the age of 70 years. Immun. Ageing 13, 1 . doi: 10.1186/s12979-015-0056-6

Pera, A., Campos, C., Lopez, N., Hassouneh, F., Alonso, C., Tarazona, R., et al. (2015). Immunosenescence: implications for response to infection and vaccination in older people. Maturitas 82, 50-55. doi: 10.1016/j.maturitas.2015.05.004

Pisa, D., Alonso, R., Rábano, A., Rodal, I., and Carrasco, L. (2015). Different Brain Regions are Infected with Fungi in Alzheimer's Disease. Sci. Rep. 5:15015. doi: $10.1038 /$ srep 15015

Prasad, J. M., Gorkun, O. V., Raghu, H., Thornton, S., Mullins, E. S., Palumbo, J. S., et al. (2015). Mice expressing a mutant form of fibrinogen that cannot support fibrin formation exhibit compromised antimicrobial host defense. Blood 126, 2047-2058 doi: 10.1182/blood-2015-04-639849

Pretorius, E., Mbotwe, S., Bester, J., Robinson, C. J., and Kell, D. B. (2016). Acute induction of anomalous and amyloidogenic blood clotting by molecular amplification of highly substoichiometric levels of bacterial lipopolysaccharide. J. R Soc. Interface 13:20160539. doi: 10.1098/rsif.2016.0539

Pussinen, P. J., Havulinna, A. S., Lehto, M., Sundvall, J., and Salomaa, V. (2011). Endotoxemia is associated with an increased risk of incident diabetes. Diabetes Care 34, 392-397. doi: 10.2337/dc10-1676

Qian, F., Wang, X., Zhang, L., Chen, S., Piecychna, M., Allore, H., et al. (2012). Age-associated elevation in TLR5 leads to increased inflammatory responses in the elderly. Aging Cell 11, 104-110. doi: 10.1111/j.1474-9726.2011.00759.x

Report, M. A. M. W. (1999). Achievements in Public Health, 1900-1999: control of infectious diseases. MMWR 48, 621-629.

Riley, J. C. (2005). Estimates of regional and global life expectancy, 1800-2001. Popul. Dev. Rev. 31, 537-543. doi: 10.1111/j.1728-4457.2005.00083.x

Riviere, G. R., Riviere, K. H., and Smith, K. S. (2002). Molecular and immunological evidence of oral Treponema in the human brain and their association with Alzheimer's disease. Oral Microbiol. Immunol. 17, 113-118. doi: 10.1046/j.0902-0055.2001.00100.x

Sato, J., Kanazawa, A., Ikeda, F., Yoshihara, T., Goto, H., Abe, H., et al. (2014). Gut dysbiosis and detection of "live gut bacteria" in blood of Japanese patients with type 2 diabetes. Diabetes Care 37, 2343-2350. doi: 10.2337/dc13-2817

Soscia, S. J., Kirby, J. E., Washicosky, K. J., Tucker, S. M., Ingelsson, M., Hyman, B., et al. (2010). The Alzheimer's disease-associated amyloid beta-protein is an antimicrobial peptide. PLoS ONE 5:e9505. doi: 10.1371/journal.pone.0009505

Spronk, H. M., van der Voort, D., and Ten Cate, H. (2004). Blood coagulation and the risk of atherothrombosis: a complex relationship. Thromb. J. 2:12. doi: $10.1186 / 1477-9560-2-12$

Tauchi, H., Sato, T., and Watanabe, T. (1999). Japanese Centenarians: Medical Research for the Final Stages of Human Aging. Aichi: Institute for Medical Science of Aging; Aichi Medical University.
Taylor, L. H., Latham, S. M., and Woolhouse, M. E. (2001). Risk factors for human disease emergence. Philos. Trans. R Soc. Lond. B. Biol. Sci. 356, 983-989. doi: $10.1098 /$ rstb.2001.0888

Tazume, S., Umehara, K., Matsuzawa, H., Aikawa, H., Hashimoto, K., and Sasaki, S. (1991). Effects of germfree status and food restriction on longevity and growth of mice. Jikken Dobutsu 40, 517-522.

Tran, L., and Greenwood-Van Meerveld, B. (2013). Age-associated remodeling of the intestinal epithelial barrier. J. Gerontol. A Biol. Sci. Med. Sci. 68, 1045-1056. doi: 10.1093/gerona/glt106

Turner, J. E., Campbell, J. P., Edwards, K. M., Howarth, L. J., Pawelec, G., Aldred, S., et al. (2014). Rudimentary signs of immunosenescence in Cytomegalovirus-seropositive healthy young adults. Age (Dordr) 36, 287-297. doi: 10.1007/s11357-013-9557-4

Velsko, I. M., Chukkapalli, S. S., Rivera, M. F., Lee, J. Y., Chen, H., Zheng, D., et al. (2014). Active invasion of oral and aortic tissues by Porphyromonas gingivalis in mice causally links periodontitis and atherosclerosis. PLoS ONE 9:e97811. doi: 10.1371/journal.pone.0097811

Weinstock, C., Ullrich, H., Hohe, R., Berg, A., Baumstark, M. W., Frey, I., et al. (1992). Low density lipoproteins inhibit endotoxin activation of monocytes. Arterioscler. Thromb. 12, 341-347.

Whitman, W. B., Coleman, D. C., and Wiebe, W. J. (1998). Prokaryotes: the unseen majority. Proc. Natl. Acad. Sci. U.S.A. 95, 6578-6583.

Williams, W. M., Torres, S., Siedlak, S. L., Castellani, R. J., Perry, G., Smith, M. A., et al. (2013). Antimicrobial peptide beta-defensin-1 expression is upregulated in Alzheimer's brain. J. Neuroinflammation 10:127. doi: 10.1186/1742-2094-10-127

Williamson, D. A., Lim, A., Wiles, S., Roberts, S. A., and Freeman, J. T. (2013). Population-based incidence and comparative demographics of community-associated and healthcare-associated Escherichia coli bloodstream infection in Auckland, New Zealand, 2005-2011. BMC Infect. Dis. 13:385. doi: 10.1186/1471-2334-13-385

Wozniak, M. A., Mee, A. P., and Itzhaki, R. F. (2009). Herpes simplex virus type 1 DNA is located within Alzheimer's disease amyloid plaques. J. Pathol. 217, 131-138. doi: 10.1002/path.2449

Yuan, X., Zhou, Y., Wang, W., Li, J., Xie, G., Zhao, Y., et al. (2013). Activation of TLR4 signaling promotes gastric cancer progression by inducing mitochondrial ROS production. Cell Death Dis. 4, e794. doi: 10.1038/cddis.20 13.334

Zhavoronkov, A., and Bhullar, B. (2015). Classifying aging as a disease in the context of ICD-11. Front. Genet. 6:326. doi: 10.3389/fgene.20 15.00326

Zhavoronkov, A., and Moskalev, A. (2016). Editorial: should we treat aging as a disease? Academic, Pharmaceutical, Healthcare Policy, and Pension Fund Perspectives. Front Genet 7:17. doi: 10.3389/fgene.2016.00017

Conflict of Interest Statement: The author declares that the research was conducted in the absence of any commercial or financial relationships that could be construed as a potential conflict of interest.

Copyright (c) 2016 Lustgarten. This is an open-access article distributed under the terms of the Creative Commons Attribution License (CC BY). The use, distribution or reproduction in other forums is permitted, provided the original author(s) or licensor are credited and that the original publication in this journal is cited, in accordance with accepted academic practice. No use, distribution or reproduction is permitted which does not comply with these terms. 